\title{
Mobile Commerce in the Automobile Industry
}

\author{
Sojen Pradhan \\ University of Technology, Sydney \\ e-mail: sojen@it.uts.edu.au
}

\begin{abstract}
E-commerce continues to grow however this will not mature until it becomes truly mobile - information available anywhere, anytime and to anybody. Applying mobile access to computing creates both tremendous commercial opportunities and complexity. It is becoming increasingly portable, as well as convenient as the wireless terminals can be installed in automobile dashboards and embedded in all manner of everyday appliances. Automobile manufacturers are beginning to offer wireless services to drivers but most in-carcommunications capabilities are still basic. Two primary areas of Telematics are:

- On-board Telematics (CD ROM) \&

- $\quad$ Call centre Telematics

It is a big potential market for car manufacturers as millions of drivers spend many hours in their cars. However, the greatest challenges to the growth of mobile commerce are security and privacy issues and hence the lack of consumer confidence in mobile network security.
\end{abstract}

\section{Keywords} WLAN

Mobile Commerce, Telematics, GPS, Bluetooth,

\section{Introduction}

Electronic commerce continues to see phenomenal growth, but most development of e-commerce involves wired infrastructures. Emerging wireless and mobile networks will provide new avenues for growth and new opportunities in mobile commerce [1].

The growth of mobile applications will change the way people live, play and do business. The following evolutionary steps clarify how this would happen:

Step 1: the user going to the computer's location (computer-centric)
Step 2: the computer is wherever the user is (personcentric) [2]

Mobile commerce is the buying and selling of goods and services through wireless hand-held devices such as mobile phones, personal digital assistants (PDAs), mp3 players, digital cameras, handheld gaming devices and computers [3]. M-commerce is facilitated by the convergence of the Internet, e-commerce and the wireless world where people can go online anytime, anywhere and using any device [2]. Some of examples of the wireless or mobile networks are GSM (Global Systems for Mobile Telecommunication), GPRS (General Packet Radio Services), CDMA (Code Division Multiple Access), Mobitex, Reflex and UMTS (Universal Mobile Telecommunication Systems) [4].

\section{Research Rationale}

This research originated as an attempt to understand why e-Business has not impacted significantly on the automobile industry. It could be surmised that mcommerce will have a greater effect as it relates to mobility as does the motor industry. The approach is to acquire in-depth knowledge of security issues in wireless technologies as well as human stakeholders concerned about privacy issues against the convenience provided by the technology. The theory and method adopted in the study is as follows:

\section{Methodology}

Clarke [5] has outlined the challenges facing researchers in the domain of Electronic commerce. The 'high volatility of the phenomenon' and lack of 'established definitions' are obstacles to researchers trying to get high quality scientific data on which to base future hypotheses.

The literature review is the primary sources of research data including the World Wide Web, online 
newspaper articles, newspapers through Factiva (Reuters and DowJones) and books such as 'M-Commerce The race to Mobility [2] and 'mCommerce Security: a beginner's guide' [4].

This research was started by investigating the initiation, development and attempted adoption of $\mathrm{m}$ commerce across the automobile market. This paper represents one research facet of this data collection. This approach is in seeking to address 'how' and 'why' questions associated with this research. In the future, the researcher will undertake structured interviews with big players of manufacturers to develop a support system to clarify doubts of potential users. This will be reported on in a later paper.

In future, the methodology will also emphasize the importance of subjective meanings in the processes through which users react to Telematics [6]. This requires the use of field studies of humans in their settings so as to describe, interpret, analyze, and understand the social world from the participant's perspective. That is, the process will be viewed as a social one, and the research will aim to capture the complex, dynamic nature of the social phenomena of Telematics. The research will seek to understand the process in practice from the participants' perspectives, with a primary focus being the meaning of the technology to the individuals as well as their expectations around its use [6], particularly with respect to their social, cultural, and work contexts.

\section{Overview of M-Commerce}

M-Commerce covers a multitude of industry sectors. Mobile phones and PDAs are frequently being used for conducting trades and logging on to wireless brokerage services in the USA. It is becoming increasingly portable as well as convenient to be installed in automobile dashboards [7]. Mobile banking is rapidly becoming a significant market for mobile consumers. Even most current news sites: CNN, Reuters, and BBC have started offering services whereby users can configure their mobile device to receive news and information content [4].

M-commerce using mobile phone or handheld devices like PDAs are outlined in the table below:
Table 1: M-commerce Examples [4]

\begin{tabular}{|c|c|}
\hline \multirow{8}{*}{ 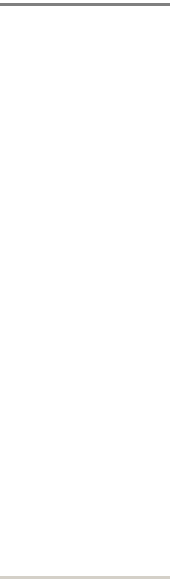 } & Paying for parking tickets \\
\hline & $\begin{array}{l}\text { Buying a drink from a vending machine } \\
\text { and charging it to the mobile phone bill. }\end{array}$ \\
\hline & $\begin{array}{l}\text { Buying an airline ticket and being } \\
\text { invoiced by a travel agent. }\end{array}$ \\
\hline & Paying for an MP3 file download \\
\hline & $\begin{array}{l}\text { Buying stocks and initiating a request to } \\
\text { have the money transferred from a } \\
\text { preconfigured bank account. }\end{array}$ \\
\hline & $\begin{array}{l}\text { Browsing through books from an online } \\
\text { bookstore on the PDA and buying }\end{array}$ \\
\hline & $\begin{array}{l}\text { Placing a purchase order over a wireless } \\
\text { network linked to a supplier's intranet }\end{array}$ \\
\hline & $\begin{array}{l}\text { Using voice recognition on a phone to } \\
\text { buy a movie ticket. }\end{array}$ \\
\hline \multirow{3}{*}{$\begin{array}{l}\text { Mobile } \\
\text { Interactions }\end{array}$} & $\begin{array}{lll}\text { Sending and receiving } & \text { SMS (short } \\
\text { message service) about products and } \\
\text { discount. }\end{array}$ \\
\hline & $\begin{array}{l}\text { Receiving an alert notification from an } \\
\text { online travel company about a new lower } \\
\text { fare. }\end{array}$ \\
\hline & $\begin{array}{l}\text { Browsing through movie listings and } \\
\text { buying a movie ticket using mobile phone } \\
\text { but paying buy credit card. }\end{array}$ \\
\hline
\end{tabular}

Implementation of wireless LAN (WLAN) has doubled over the last year in the USA according to Yankee Group. WLAN access points are becoming more common in malls, restaurants, and other high traffic locations [8]. It has been expected that $40 \%$ of consumer-to-business e-commerce will come from smart phones using the wireless application protocol (WAP) by 2004, according to the GartnerGroup, a market research firm [9].

\section{Functional Platforms of Mobile Commerce Applications}

As discussed earlier, there are many ways mobile devices are used to conduct business and exchange information. The emerging unlimited number of potential mobile commerce applications can be classified into the following five platforms set out in the following table: 
Table 2: Functional Platform of mCommerce Applications [4]

\begin{tabular}{||l||l||l||l||l||}
\hline \hline $\begin{array}{l}\text { Messaging } \\
\text { Services }\end{array}$ & $\begin{array}{l}\text { Web Access } \\
\text { services }\end{array}$ & $\begin{array}{l}\text { Voice Activated } \\
\text { Services }\end{array}$ & $\begin{array}{l}\text { Location Based } \\
\text { Services }\end{array}$ & $\begin{array}{l}\text { Digital Content } \\
\text { Services }\end{array}$ \\
\hline $\begin{array}{l}\text { sms or email } \\
\text { information } \\
\text { services }\end{array}$ & $\begin{array}{l}\text { Format website for } \\
\text { display on mobile } \\
\text { devices }\end{array}$ & $\begin{array}{l}\text { Voice response } \\
\text { paradigm to } \\
\text { navigate Websites }\end{array}$ & $\begin{array}{l}\text { Bluetooth and } \\
\text { GPS contributing } \\
\text { to this services }\end{array}$ & $\begin{array}{l}\text { Containing some } \\
\text { digital files like } \\
\text { music or movie }\end{array}$ \\
\hline $\begin{array}{l}\text { Examples: } \\
\text { weather reports, } \\
\text { financial info, } \\
\text { traffic info, } \\
\text { directory } \\
\text { assistance }\end{array}$ & $\begin{array}{l}\text { GoAmerica, } \\
\text { OmniSky, } \\
\text { AvantGo, } \\
\text { Openwave }\end{array}$ & $\begin{array}{l}\text { VoiceXML from } \\
\text { AT\&T, Lucent, } \\
\text { Motorola and IBM }\end{array}$ & $\begin{array}{l}\text { Driving directions, } \\
\text { booking hotels or } \\
\text { restaurants }\end{array}$ & $\begin{array}{l}\text { e-Book in a PDA, } \\
\text { e-music, Atom } \\
\text { Films (Short } \\
\text { animated feature) }\end{array}$ \\
\hline
\end{tabular}

\section{Mobile Commerce in the Automobile Industry}

Electronic commerce has not affected the automotive industry as strongly as other consumer goods industries. So far, it has brought some cost savings for vehicle manufacturers by enabling them to streamline both supply-chain and retail processes [10]. Automobile manufacturers are beginning to offer wireless services to drivers. Mobile commerce will have a more fundamental impact: changing the features of the vehicle itself, and challenging car companies to become "mobility service providers".

\section{Telematics}

Telematics is the combination of the technologies of the Internet, the mobile phone and the automobile to provide increased safety and productivity by delivering better service and enjoyable trip for consumers. It is a mechanism for transforming the automobile into the mobile portal or a hands-free in-vehicle communication system [11]. In the past there have been two primary areas:

- On-board Telematics - This system stores information on CD-ROMs that are located in the car, along with location positioning technology. Road maps in this form are most of time out-ofdate.

- Call centre Telematics - This relies on phone calls to a call centre. Call centre lacks scalability and are prone to human error. Too expensive to run the centre. [12]
Mercedes-Benz was one of the first companies to describe "Telematics" as automotive communication technologies introducing SOS service (TeleAid) and followed by GM's On-Star and Ford's RESCU. The use of a GPS along with location-based mobile technology allow the service provider to assist drivers by providing directions, maps, traffic information and emergency roadside assistance. Car manufacturers are increasingly bringing wireless capabilities to their vehicles such as downloading music, returning email and on-the-road shopping. As market penetration increases and eventually demand for enriched content grows, and Telematics will become as a channel of information and entertainment. Drivers will be able turn on home lights, start and stop the sprinkler system, set their office and home security systems [2].

The Telematics Research Group predicts that nearly $21 \%$ of U.S. drivers will own vehicles that include some form of Telematics by 2006 . Remote vehicle diagnostics and consumer desire for increased safety and security are driving the Telematics market in the fast lane [13].

\section{Bluetooth}

Bluetooth is a computing and telecommunication industry specification outlines on how mobile devices can interconnect with each other with home, business phones and computers using a short-range wireless communication [3].

Future Bluetooth-based automotive applications are poised to deliver new opportunities to all facets of the industry from silicon vendors and hardware manufacturers, to automakers and gasoline retailers. 
DaimlerChrysler's UConnect hands-free car kit, currently available as an option on certain Chrysler vehicles, serves as Bluetooth's U.S. introduction. Meanwhile in Europe, specific Saab and BMW models will also offer Bluetooth hands-free car kits as options [14]. Using Bluetooth to communicate with any mobile phone both in and out of the car, the unit includes a dashboard-mounted receiver and a microphone embedded in the rearview mirror and phone. While the system works with any carrier and phone number [13].

\section{Business alliances for improved Telematics}

The Carucel infrastructure is the fourth generation (4G) technology that allows this necessary high bandwidth capacity (20 Mbps vs. $144 \mathrm{Kbps}$ with $3 \mathrm{G}$ ) while driving along the highway [15]. This high bandwidth capacity is critical for the mobile Internet which is expected to be the next tremendous growth area for wireless technology as evidenced by companies such as given below in the table.

Table 3: Business Alliances [15], [13]

\begin{tabular}{|l|l|}
\hline $\begin{array}{l}\text { Corporate } \\
\text { Partners }\end{array}$ & Products \\
\hline $\begin{array}{l}\text { Microsoft \& } \\
\text { General Motors }\end{array}$ & Cars with Internet \\
\hline $\begin{array}{l}\text { Ericsson, Telia } \\
\text { Volvo }\end{array}$ & WirelessCar Project \\
\hline $\begin{array}{l}\text { IBM \& } \\
\text { Motorola }\end{array}$ & $\begin{array}{l}\text { Wireless Internet Technology for } \\
\text { cars to enable drivers to send emails, } \\
\text { check on stocks and others }\end{array}$ \\
\hline $\begin{array}{l}\text { Oracel \& } \\
\text { Wingcast }\end{array}$ & $\begin{array}{l}\text { Telematics application Wingcast ( } \\
\text { joint venture of Ford and Qualcomm) } \\
\text { currently has agreements with Ford } \\
\text { and Nissan }\end{array}$ \\
\hline $\begin{array}{l}\text { Microsoft with } \\
\text { Clarion, } \\
\text { Daewoo \& Intel }\end{array}$ & $\begin{array}{l}\text { Navigation system in the car } \\
\text { dashboard }\end{array}$ \\
\hline $\begin{array}{l}\text { Sony Ericsson } \\
\text { and Chapman } \\
\text { Technologies }\end{array}$ & $\begin{array}{l}\text { Vehicle Security and } \\
\text { Communications Applications }\end{array}$ \\
\hline GM \& AOL & Cars with Internet \\
\hline GM \& Sony & Cars with Internet \\
\hline Ford \& Yahoo & Cars with Internet \\
\hline $\begin{array}{l}\text { Ford \& Volvo } \\
\text { with Vodafone }\end{array}$ & Telematics based on GSM \\
\hline
\end{tabular}

However, president CEO of ATX technologies Inc., the leading independent Telematics service provider to the automotive industry, emphasized on vRM (vehicle relationship management) and said, "In the five years we've been in the Telematics industry, ATX has learned that Telematics is all about customer satisfaction and customer satisfaction and customer loyalty, not creating a new business line or a mobile comer portal." [16].

A new generation of Telematics will not only transmit location information but it also transmit a variety of data such as warning that electronic safety features of the automobile, designed to combat slippery road conditions, triggered at a specific time and location, at a specific speed. Convenient services enabled by new generation of systems, promote changes of lifestyle providing both location-based and context-aware services [17].

During next decade, drivers will find new cars equipped with wireless connectivity as a standard feature. As road congestion continues to increase, this feature will offer driver and passengers mobile services to exploit dead time lost in traffic with precise real-time information systems. This information also could be used to implement tidal routes, temporarily switching the direction of unused lanes in response to traffic demand and hence for the optimization of road space, traffic speed and journey times. This system will also help some authorities' desires to collect tolls more efficiently, facilitate emergency services access to incidents and allow police forces to isolate fleeing criminals rapidly [2].

The benefit offered by each convenience is associated with a loss of privacy. So mobility and the convenience of ubiquitous connectivity may be seen as a clear advantage of wireless technology, however these systems conflict with citizens' rights to privacy in their movements [18].

The major challenge to make automobile a "mobility service provider" is to gain public acceptance of the technology and improve the security level in wireless technology. It is expected that enhanced vehicle safety Telematics features and vehicle relationship management (VRM) (customer-vehicle relationship) will provide customer satisfaction and increase customer loyalty to gain market place popularity. In order to improve the trust and security level, wireless encryption protocol (WEP) will be used to provide encryption over wireless network connections.

\section{Conclusion}

Mobile commerce is complementary to e-commerce. To extract value from e-commerce applications, new mobile application are needed that enable unprecedented ease 
and speed of information access. However, it is certain that the mobile revolution will create tremendous opportunities for some companies and be a terrible threat to those who insist on status quo [2]. The future of Telematics shows promise but most in-carcommunications capabilities are still basic.

Further research hopes to explore the greatest challenges to the growth of mobile commerce, security and privacy issues in mobile network security. Mobile commerce security equals Internet security plus wireless security. Wireless adds another layer of complexity and risk to safeguarding information because the infrastructure for $\mathrm{m}$-commerce is much less mature, less reliable, and more vulnerable to a security breach by the very nature of how a wireless transaction is made [19].

\section{References}

[1] Varshney, U., Vetter, R.J. \& Kalakota, Ravi, Sept 19, 2002, "Mobile Commerce: A New Frontier", IEEE Computer Society, http://www.computer.org./computer/articles October/Varshney/Varsheney.html

[2] Kalakota, Ravi \& Robinson, 2001, Marcia, "M-Business: The Race to Mobility", McGraw-Hill.

[3] Lawrence, Elaine \& et.al., 2002., "Technology of internet business" John Wile and Sons Australia.

[4] Raina, Kapil \& Harsh, Anurag, 2002 "mCommerce Security: a beginner's guide" McGraw-Hill/Osborne.

[5] Clarke, R., 1999, "Appropriate Research for Electronic Commerce", Xamax Consulting, http://www.xamax.com.au. [6] Orlikowski WJ and Baroudi JJ (1991) "Studying information technology in organizations: research approaches and assumptions", Information System Research, March, 1-25.
[7] Kobielus, James, Mar. 27, 2000 "WAP will dominate and complicate e-commerce", Network World, Vol. 17, p.49.

[8] e-Business Advisor, "Mobile business on the rise", 01 September 2002, Vol. 20, Issue 7 FACTIVA.

[9] Haskin, D. 3 November. 1999, "Analysts: Smart Phones to lead E-Commerce Explosion”, allNetDevices.

[10] Whitepapers,http://itpapers.cnet.com/whitepapers/ papergateway.asp?WID $=564954515859$ \& referrer $=$ cnet

[11] Evans, N. Mar. 19, 2001, "Don't Forget to Plan for Access in Cars", InternetWeek, no.853, p. 17.

[12] Walser, Mark, April 11, 2001 "Telematics: Your car's Collision with Commerce", M-Commerce Times.

[13] Sutherland, Ed, November 19, 2001 "Putting M-

Commerce in the Driver's seat", M-Commerce Times. http://www.mcommercetimes.com/Technology/188

[14] Telematicsupdate, October 19, 2002, http://www.telmaticsupdate.com "Telephone only the beginning for Bluetooth in the vehicle, according to ABI". [15] Carucel October10, 2002, http://www.carucel.com/ Market.htm, Mobile Wireless Market.

[16] Autoparts Report, (2001) "Telematics Industry Shakeout Predicted (by Steve Millstein of ATX Technologies)", 18 November 2001, Vol. 15, no. 5.

[17] Ng-Kruelle, Swatman, Paul A., Rebne, Douglas S., \& Hampe, Felix, November, 2001 "The Price of Convenience: Privacy and Mobile commerce", apache.iwi.unikoblenz.de:8080/iwi/bks/publikationen.

[18] May, Paul, 2001 "Cars: The Sit-in Mobile Devices", Mobile Commerce: Opportunities, applications and technologies of wireless business, Cambridge University Press, UK.

[19] Emmerson, Bob, 2001, "Is M-commerce flying without a Net?" http://www.amscatalyst.com. 